City University of New York (CUNY)

CUNY Academic Works

2020

\title{
A Different Set of Rules? NLRB Proposed Rule Making and Student Worker Unionization Rights
}

William A. Herbert

CUNY Hunter College

Joseph van der Naald

CUNY Graduate Center

\section{How does access to this work benefit you? Let us know!}

More information about this work at: https://academicworks.cuny.edu/gc_pubs/591

Discover additional works at: https://academicworks.cuny.edu

This work is made publicly available by the City University of New York (CUNY).

Contact: AcademicWorks@cuny.edu 


\title{
Journal of Collective Bargaining in the Academy
}

Volume 11 Some Impacts on Faculty: 50+ Years

of Academic Collective Bargaining and

Article 1

Counting

March 2020

\section{A Different Set of Rules? NLRB Proposed Rule Making and Student Worker Unionization Rights}

\author{
William A. Herbert \\ CUNY Hunter College, wh124@hunter.cuny.edu \\ Joseph van der Naald \\ CUNY Graduate Center, jvandernaald@gradcenter.cuny.edu
}

Follow this and additional works at: https://thekeep.eiu.edu/jcba

Part of the Collective Bargaining Commons, Higher Education Commons, Labor and Employment Law Commons, and the Legal Commons

\section{Recommended Citation}

Herbert, William A. and van der Naald, Joseph (2020) "A Different Set of Rules? NLRB Proposed Rule Making and Student Worker Unionization Rights," Journal of Collective Bargaining in the Academy: Vol. 11 , Article 1.

Available at: https://thekeep.eiu.edu/jcba/vol11/iss1/1

This Article is brought to you for free and open access by the Journals at The Keep. It has been accepted for inclusion in Journal of Collective Bargaining in the Academy by an authorized editor of The Keep. For more information, please contact tabruns@eiu.edu. 


\section{A Different Set of Rules? NLRB Proposed Rule Making and Student Worker Unionization Rights}

\section{Cover Page Footnote}

The authors wish to express their appreciation to St. John's University School of Law student Elyssa Carr Cisluycis and Hunter College student Allison Stillerman for their research assistance. In addition, we thank the dedicated staff of the University of Wisconsin-Madison Archives, the New York State Archives, and the Oregon Employment Relations Board who helped provide access to primary source materials about early representation efforts involving student employees. 


\title{
A Different Set of Rules? NLRB Proposed Rule Making and Student Worker Unionization Rights
}

\author{
William A. Herbert ${ }^{1}$ and Joseph van der Naald ${ }^{2}$
}

\section{Introduction}

On September 23, 2019, the National Labor Relations Board (NLRB) published a Notice of Proposed Rulemaking (NPRM) in the Federal Register (Jurisdiction-Nonemployee Status of University and College Students Working in Connection with Their Studies, 2019) to exclude graduate assistants and other student employees from employee status under Section 2(3) of the National Labor Relations Act (NLRA). ${ }^{3}$ Final adoption of the rule would reverse the NLRB's decision in Columbia University (2016), and thereby deprive graduate assistants and other students working for private colleges and universities from core NLRA rights: the right to union representation and collective bargaining, to engage in concerted activities for mutual aid and protection, and protections against retaliation and discrimination for engaging in concerted protected activities.

Historically, it has been an NLRB practice to await adjudicated cases before revisiting prior decisions involving policy questions and statutory interpretations. Until now. Although the NLRB has broad rulemaking authority, ${ }^{4}$ it has previously applied that regulatory power conservatively, and focused it on such issues as the necessary amount of gross revenue of a

\footnotetext{
${ }^{1}$ William A. Herbert is a Distinguished Lecturer at Hunter College, City University of New York, and Executive Director of the National Center for the Study of Collective Bargaining in Higher Education and the Professions (National Center).

${ }^{2}$ Joseph van der Naald is a Ph.D. student in the sociology program at the CUNY Graduate Center and a National Center graduate research fellow.

329 U.S.C. § 152(3) of the National Labor Relations Act states: "The term "employee" shall include any employee, and shall not be limited to the employees of a particular employer, unless this subchapter explicitly states otherwise, and shall include any individual whose work has ceased as a consequence of, or in connection with, any current labor dispute or because of any unfair labor practice, and who has not obtained any other regular and substantially equivalent employment, but shall not include any individual employed as an agricultural laborer, or in the domestic service of any family or person at his home, or any individual employed by his parent or spouse, or any individual having the status of an independent contractor, or any individual employed as a supervisor, or any individual employed by an employer subject to the Railway Labor Act [45 U.S.C. $§ 151$ et seq.], as amended from time to time, or by any other person who is not an employer as herein defined" (National Labor Relations Act of 1935).
}

${ }^{4} 29$ U.S.C. $\S 156$ of the National Labor Relations Act states: "The Board shall have authority from time to time to make, amend, and rescind, in the manner prescribed by subchapter II of chapter 5 of Title 5, such rules and regulations as may be necessary to carry out the provisions of this subchapter." (National Labor Relations Act of 1935). See, National Labor Relations Bd. v. Bell Aerospace Co. (1974).

Vol. 11, December, 2019 (March, 2020)

(C) 2019 National Center for the Study of Collective Bargaining in Higher Education 
nonprofit college for it to assert jurisdiction, ${ }^{5}$ bargaining unit structure for the healthcare industry, and the agency's representation procedures (American Hospital Ass' $n$ v. NLRB, 1991; Associated Builders and Contractors of Texas, Inc. v. NLRB, 2016).

Following the appointment of John F. Ring as NLRB Chairman on April 12, 2018, however, the agency has embarked on a regulatory agenda to remake precedent through rulemaking on procedural and substantive issues. One such issue is the proper standard for determining joint-employer status under the NLRA. On February 26, 2020, the NLRB issued a final rule concerning joint-employers. (Joint-Employer Status Under the National Labor Relations Act, 2020). The new joint-employer rule amends current law by substantially restricting when private employers can be subject to joint-employer liability (Kanu, 2020). The new rule impacts higher education to the extent that institutions continue to adopt business models from for-profit industries like relying on employment agencies to hire temporary faculty and expanding the use of private contractors for campus-based work previously performed by university employees (Hyman 2018; Weil, 2014) Another substantive issue that the current NLRB Board has chosen to revisit through a proposed rule is the employee status of student workers on private college campuses under the NLRA (NLRB, 2019).

The proper application of NLRB rulemaking power is a subject that has been debated for decades, well before Chairman Ring's appointment. The debate is reflected in the body of academic literature that has examined the merits and appropriateness of the NLRB invoking its rulemaking powers (Garden, 2014, pp. 1469, 1471-1477).

Concurrently with rulemaking, the current Board majority is acting swiftly to impose its activist agenda through decisions in adjudicated cases, reversing or substantially modifying prior precedent on many important topics including: finding that gig drivers do not have employee status under the NLRA (SuperShuttle DFW, Inc. 2019); narrowing the scope of protected concerted activities (Alstate Maintenance, LLC, 2019); concluding that employees do not have a right to engage in protected activity on an employer's email system (Caesars Ent., 2019); expanding the power of employers to make unilateral changes (MV Transp., Inc, 2019); upholding the legality of employer-mandated confidentiality during investigations (Apogee Retail LLC v. Kathy Johnson, 2019); denying the right of nonemployee union representatives to be present on employer property that is open to the general public (UPMC, 2019); granting greater deference to arbitration awards (Atkinson v. United Parcel Serv., Inc., 2019); and

\footnotetext{
${ }^{5}$ Colleges and Universities (1970) states "The Board will assert its jurisdiction in any proceeding arising under sections 8,9 , and 10 of the Act involving any private nonprofit college or university which has a gross annual revenue from all sources (excluding only contributions which, because of limitation by the grantor, are not available for use for operating expenses) of not less than $\$ 1$ million."
} 
diminishing the legality of employees wearing union insignia during work time (Wal-Mart Stores, Inc., 2019).

The NLRB has articulated four reasons for choosing to proceed with rulemaking rather than await an appropriate case to revisit the question of the employee status of student workers: the question involves an industry-wide determination; the rulemaking procedure allows for broader public input; a rule would result in greater predictability for higher education institutions, student workers, and unions; and that rulemaking will "not depend on participation and argument by parties in a specific case, and it cannot be mooted by developments in a pending case" (Jurisdiction-Nonemployee Status of University and College Students Working in Connection with Their Studies, 2019).

The last reason for the initiation of the rulemaking process, and perhaps the central one, is the NLRB's frustration at the lack of a pending case to rule on the issue, which is reflected in the following statement: "we note that the student employee issue has been raised recently by requests for review in several cases pending before the Board, but in each of those cases the issue was mooted by withdrawal of the underlying representation petition" (Jurisdiction-Nonemployee Status of University and College Students Working in Connection with Their Studies, 2019). The centrality of this reason is supported by the fact that the NLRB did not invoke rulemaking to determine the employee status of gig workers in the transportation industry (SuperShuttle DFW, Inc., 2019). The administrative activism of the current NLRB Board contrasts with the general pragmatism applied by state labor relations agencies (Herbert, 2018).

In response to the NLRB's NPRM, the National Center for the Study of Collective Bargaining in Higher Education and the Professions (National Center) submitted public comments to the agency on November 20, 2019. This article is a modified version of those comments, which were aimed at informing the NLRB's rule making process through information concerning the entire higher education industry. The information falls into four categories:

- Definitions, data, and analyses concerning graduate assistants by the United State Department of Labor Bureau of Labor Statistics and the United States Department of Education's National Center for Education Statistics. They demonstrate that the NLRB's proposed rule would exclude from NLRA coverage over 81,000 graduate assistants working in occupations at private institutions that other federal government agencies treat as distinct from the classification of graduate student;

- The half-century of history and legal precedent concerning collective bargaining by graduate assistants and other student employees under state constitutions and collective bargaining laws in 14 States and Canadian provinces. The history includes collective 
bargaining relationships established at the City University of New York (CUNY) and the University of Wisconsin-Madison in 1969, at the University of Oregon in 1970, and at Rutgers University in the early 1970s;

- Collective bargaining unit data maintained by the National Center demonstrating that there are currently 68,442 graduate assistants and other student employees covered under current collective bargaining agreements and an additional 13,039 graduate and undergraduate assistants in new bargaining units without first contracts. These figures are based on data collected by the National Center for the period of 2013-2019 along with data from the National Center's 2012 Directory of U.S. Faculty Bargaining Agents in Institutions Higher Education (Berry and Savarese, 2012). ${ }^{6}$

- The terms of 42 current collective bargaining agreements at institutions of higher education involving graduate and undergraduate student employees. The most common provisions are wages, grievance-arbitration, management rights, non-discrimination, terms of appointment, and union security. Many contracts also include no-strike, academic freedom, and retirement provisions.

Rulemaking provides the NLRB with an opportunity to examine this information concerning the higher education industry before adopting a final rule. Indeed, access to empirical evidence and economic studies was one of the reasons cited by New York University law professor Samuel Estreicher for encouraging the agency to utilize rulemaking (Estreicher, 1985, p. 176). Seattle University law professor Charlotte Garden has summarized this rationale in the following manner:

More \& Better Information: The rulemaking process allows all interested constituencies to submit comments, and the resulting empirical record could lead to better decision making by the Board. In other words, the rulemaking process allows for greater public participation than the adjudicatory process - a feature that offers advantages in terms of democratic process, as well as the final result. In contrast, adjudication is limited to the parties before the Board, plus amici. Even where amicus participation in adjudication is robust - and therefore yields much of the same information that a rulemaking process would - there is some loss from a public participation standpoint; amici will probably be insiders, as it is simply more difficult to figure out how to draft and file an amicus brief than a comment. Further, the

\footnotetext{
${ }^{6}$ Until relatively recently, the National Center's research agenda focused primarily on tenured and tenure-track faculty with little attention given to non-tenure track faculty, graduate assistants, and non-academic employees. For a recent National Center analysis of strike data involving faculty, graduate students, and others working on campus see Herbert \& Apkarian (in press).
} 
Board's response to submitted comments (both for and against) is likely to be quite thorough, which might prompt "increased deference from courts (Garden, 2014, p. 1475).

Ironically, one reason that rulemaking might be necessary is the frequently overlooked element of the Taft-Hartley Act (Labor-Management Relations Act of 1947) that prohibits the NLRB from appointing anyone to engage in economic analysis (National Labor Relations Act of 1935). ${ }^{7}$ This anti-intellectual prohibition precludes the agency from recreating its Division of Economic Research to study the economy-wide changes in the nature of work in the $21^{\text {st }}$ Century as well as the economic impact of unionization and collective bargaining in various industries including higher education (Hafiz, 2017).

\section{The Status of Graduate Assistants Defined by Other Federal Agencies}

Directly relevant to the NLRB's rulemaking process are the definitions, data, and analysis of the United States Department of Labor's Bureau of Labor Statistics (BLS) concerning the employee status of graduate assistants in higher education. BLS recognizes that graduate assistants have an economic relationship at both the public and private institutions that make up the higher education industry. In fact, BLS defines the position of graduate assistant as an occupation, and it draws an explicit definitional dichotomy between that occupation and the status of a graduate student.

BLS has classified the position of a graduate assistant in higher education as an occupation since at least 1982. The 2018 Standard Occupational Classification System (SOCS) places graduate assistants into three distinct occupational categories: Graduate Assistants (Teaching); Graduate Assistants (Research) and Graduate Assistants (Other) (Bureau of Labor Statistics, U.S. Department of Labor, 2018).

BLS describes the work done by graduate teaching assistants in higher education as "performing teaching or teaching-related duties, such as teaching lower level courses, developing teaching materials, preparing and giving examinations, and grading examinations" and understands that graduate assistants must be enrolled in a graduate student school program. In contrast, BLS does not define "graduate student" as an occupation but rather as a "student who holds a bachelor's degree or above and is taking courses at the post baccalaureate level. These students may or may not be enrolled in graduate programs." (Bureau of Labor Statistics, U.S. Department of Labor, 2018).

\footnotetext{
729 U.S.C. $\S 154$ of the National Labor Relations Act states, in part: Nothing in this subchapter shall be construed to authorize the Board to appoint individuals for the purpose of conciliation or mediation, or for economic analysis (National Labor Relations Act of 1935).
} 
Consistent with its definitional categories, BLS defines the compensation received by graduate assistants as wages for work performed. Table 1 is the May 2017 BLS table displaying the percentile annual wage estimates of graduate teaching assistants.

\section{Table 1}

BLS Occupational Employment and Wages, May 2017

$\begin{array}{lccccc}\text { Percentile } & 10 \% & 25 \% & \begin{array}{c}50 \% \\ (\text { Median) }\end{array} & 75 \% & 90 \% \\ \text { Annual Wage (2) } & \$ 17,970 & \$ 20,180 & \$ 32,460 & \$ 45,860 & \$ 58,450\end{array}$

Note: 25-1191 Graduate Teaching Assistants

A second federal agency, the United States Department of Education's National Center for Education Statistics (NCES), applies the BLS definitions when it collects and analyzes data for its Integrated Postsecondary Education Data System (IPEDS). IPEDS employs the BLS glossary concerning the entire higher education industry, including private and public sector institutions.

\section{Proposed Rule Affects Over 81,000 Graduate Assistants at Private Institutions}

IPEDs data demonstrates that final adoption of the proposed NLRB rule would result in 81,390 graduate assistants at over 500 private institutions being excluded from NLRA coverage, which would constitute the largest per se exclusion of workers since the Taft-Hartley Act (Labor-Management Relations Act of 1947). According to IPEDs, there were a total of 377,750 graduate assistants at 1,013 private and public institutions of higher education in the Fall 2017. Slightly over 50\% (518) are private institutions with a cumulative total of 81,390 graduate assistants. The remaining schools (494) are public institutions, with a cumulative total of 296,360 graduate assistants. A recent study by the Economic Policy Institute found that the exclusion of graduate assistants from collective bargaining rights would impact over $20 \%$ of the instructional academic workforce in higher education (McNicholas et al., 2019).

\section{Years of Student Employee Unionization Precedent and Experience}

The NLRB's notice of proposed rulemaking reviews at great length the agency's decisional oscillation over the decades concerning the employee status of students performing work for compensation in higher education. It is silent, however, concerning the deep and rich well of precedent and experience regarding unionization and collective bargaining at higher education institutions across the country. As Oliver Wendell Holmes, Jr. (1881/2017) stated in his legal treatise: "The life of the law has not been logic: it has been experience" (p. 1). Indeed, 
experience was the foundation for the enactment of the NLRA and the United States labor policy of encouraging the practice and procedure of collective bargaining. ${ }^{8}$

\section{The NLRB's History of Inconsistencies About Employee Status of Student Workers}

In a 2019 federal appellate decision upholding the NLRB's certification of a union to represent student library employees at the University of Chicago, ${ }^{9}$ the court aptly stated that "It is safe to say that over the last several decades, the Board has been consistently inconsistent about whether students employed by their educational institution are 'employees' entitled to collectively bargain under the National Labor Relations Act” (Univ. of Chicago v. NLRB, 2019).

Unstated in the appellate decision is the cause for the NLRB's gyrations on the statutory status of student employees: the changing composition of the NLRB Board. While NLRB members are nominated by the President and subject to Senate confirmation, it would nevertheless be an error to view the agency's flip-flops as solely a consequence of partisan politics. A far more important reason is the ideological predisposition of Board members concerning the balance between the fundamental labor rights granted by the NLRB and common law property and managerial rights. However, the association between politics and ideology at the NLRB has become more pronounced over the past few decades. Former NLRB Chairman

\footnotetext{
${ }^{8} 29$ U.S.C. $\S 151$ of the National Labor Relations Act states, in part: "Experience has proved that protection by law of the right of employees to organize and bargain collectively safeguards commerce from injury, impairment, or interruption, and promotes the flow of commerce by removing certain recognized sources of industrial strife and unrest, by encouraging practices fundamental to the friendly adjustment of industrial disputes arising out of differences as to wages, hours, or other working conditions, and by restoring equality of bargaining power between employers and employees.

Experience has further demonstrated that certain practices by some labor organizations, their officers, and members have the intent or the necessary effect of burdening or obstructing commerce by preventing the free flow of goods in such commerce through strikes and other forms of industrial unrest or through concerted activities which impair the interest of the public in the free flow of such commerce. The elimination of such practices is a necessary condition to the assurance of the rights herein guaranteed.

It is hereby declared to be the policy of the United States to eliminate the causes of certain substantial obstructions to the free flow of commerce and to mitigate and eliminate these obstructions when they have occurred by encouraging the practice and procedure of collective bargaining and by protecting the exercise by workers of full freedom of association, self-organization, and designation of representatives of their own choosing, for the purpose of negotiating the terms and conditions of their employment or other mutual aid or protection" (emphasis added) (National Labor Relations Act of 1935).

${ }^{9}$ The University of Chicago unsuccessfully challenged the NLRB certification of the International Brotherhood of Teamsters to represent the following unit of graduate and undergraduate student library employees following an election where the employees voted 67-13 in favor of unionization: "Included: All hourly paid student employees of the University of Chicago Libraries, including students employed at the Joseph Regenstein Library, the Joe and Rika Mansueto Library, Eckhart Library, John Crerar Library, D'Angelo Law Library, and the Social Services Administration Library. Excluded: All employees represented by other labor organizations and covered by other collective-bargaining agreements, temporary employees, managerial employees, guards, and professional employees and supervisors as defined in the National Labor Relations Act" (Univ. of Chicago, 2018).
} 
William Gould has described the current NLRB Board majority as "entirely predictable along ideological lines" (Antonyan, 2020).

The trajectory of NLRB case law begins, ironically, with a 1972 decision in a representation case where a university did not dispute that graduate assistants were employees under the NLRA. Instead, the institution argued that the graduate assistants should bargain together with faculty and other professionals. In Adelphi University, the NLRB rejected the university's argument that graduate assistants should be in the same bargaining unit with fulltime and part-time faculty and librarians that the American Association of University Professors (AAUP) and the United Federation of College Teachers, Local 1460, AFT, AFL-CIO (UFCT) were competing to represent. The dispute over unit composition in that case led the NLRB to issue its first decision finding graduate assistants to be "primarily students," despite being compensated for their teaching and research duties (Adelphi Univ., 1972; Coll. of

Pharmaceutical Sciences in the City of New York, 1972).

In the following year, the NLRB excluded student employees from a proposed bargaining unit of dining staff at Cornell University (Cornell Univ., 1973), and graduate and undergraduate employees from a proposed clerical and administrative unit at Barnard College (Barnard College, 1973). Neither decision, however, was based on a determination that the student employees were not covered under the NLRA.

In 1974, the NLRB issued decisions finding research assistants in Stanford University's physics department to be excluded from the protections of the NLRA (Leland Stanford Junior Univ., 1974), and that part-time student cafeteria workers employed by a private contractor on the campus of the University of California at Davis should not be in the same bargaining unit with full-time non-student workers based, in part, "on the fact that the students' employment was incidental to their academic objectives" (Saga Food Serv., 1974). ${ }^{10}$

Two years later, the NLRB ruled that part-time student janitors were not entitled to union representation due to the temporary nature of their employment and "by the fact that students are concerned primarily with their studies rather than with their part-time employment" (San Francisco Art Inst., 1976). It determined in another case that year that interns, residents, and clinical fellows at a teaching hospital were primarily students and therefore excluded from the

\footnotetext{
${ }^{10}$ See also, Saga Dining Halls, Inc. (N.Y.S. Labor Relations Bd.1966) where the New York State Labor Relations Board excluded student dining hall employees on the grounds that their employment "is wholly incidental to their basic purpose there the acquisition of a college education. It is a means to an end, not an occupation" (p. 187), and Faculty-Student Association of State University of New York at Stony Brook, Inc. (N.Y.S. Labor Relations Bd. 1973) (where the same state agency concluded that student food service employees were employees and should be included in a bargaining unit that includes non-student employees.)
} 
definition of employee under the NLRA (Cedars-Sinai Med. Ctr., 1976; St. Clare's Hosp. and Health Ctr., 1977).

Over the next two decades, the law excluding student employee unionization rights in the private sector remained the same. The status of the law did not, however, deter graduate assistants at private institutions from seeking to unionize. The most well-known organizing effort took place at Yale University in the early 1990s. There, graduate assistants formed a union and demanded to negotiate over their working conditions. When the university refused to bargain, approximately 200 graduate assistants engaged in a well-publicized grade strike at the end of the fall 1995 semester. Although they refused to submit final grades, most of the graduate assistants continued to perform other job duties. As a result, their collective action was found by the NLRB to be an unprotected partial strike (Yale Univ., 1999; DeCew, 2003, pp. 90-91).

The law began to change in late 1999 when the NLRB in Boston Medical Center Corp. (1999), substantially modified its approach to determining employee status based on Supreme Court precedent by applying the common law standard for determining employer-employee relationships to the NLRA (Sure-Tan, Inc. v. NLRB, 1984; NLRB v. Town \& Country, 1995). As a result, the NLRB reversed its earlier precedent and concluded that interns and residents were employees entitled to collective bargaining rights. In reaching that result, the agency cited public sector precedent finding interns and residents had the right to union representation and collective bargaining. ${ }^{11}$

A year later, in New York University (2000), the NLRB relied on the Boston Medical Center Corp. decision to reverse its prior precedent and concluded that graduate assistants at that university were statutory employees under the NLRA. The 2000 New York University ruling led to the certification of the United Auto Workers (UAW) to represent NYU graduate assistants and resulted in the first graduate assistant collective bargaining agreement in the private sector. The NLRB decision and the bargaining that followed sparked a renewed wave of unionization efforts by graduate assistants at Yale University, Brown University, Tufts University, and at public universities (DeCew, 2000, pp. 91-95).

\footnotetext{
11 "Further, we reach our decision here to overrule Cedars-Sinai and its progeny on the basis of our experience and understanding of developments in labor relations in the intervening years since the Board rendered those decisions. Almost without exception, every other court, agency, and legal analyst to have grappled with this issue has concluded that interns, residents, and fellows are, in large measure, employees. ... Further, we reach our decision here to overrule Cedars-Sinai and its progeny on the basis of our experience and understanding of developments in labor relations in the intervening years since the Board rendered those decisions. Almost without exception, every other court, agency, and legal analyst to have grappled with this issue has concluded that interns, residents, and fellows are, in large measure, employees" (Boston Med. Ctr. Corp., 1999, p. 163).
} 
The NLRB holding in New York University was short lived. In Brown University (2004), a new NLRB majority overruled New York University, concluding that teaching and research assistants are primarily students and their relationship with their institution was ultimately educational and not economic.

Following the Brown University decision, NYU refused to continue negotiations with the UAW for a successor agreement after the union rejected the university's final offer (Finder, 2005). The university's refusal to continue to recognize the UAW led to a graduate student strike in 2005 (Buschsbaum et al., 2006).

In 2013, NYU reversed course and negotiated an agreement with the UAW creating a procedure under which the university would voluntarily recognize the union again if the graduate assistants voted in favor of representation in an election conducted by the American Arbitration Association rather than the NLRB (Greenhouse \& Kraminer, 2013; Thornton, 2013). The alternative voluntary non-governmental procedure was necessitated by the state of the law under the Brown University decision.

In a joint statement announcing the agreement, NYU and the UAW stated, in part: this agreement [is] an opportunity to prove again that bargaining for graduate employees can be effective in a private university. The Union and the University are pleased by the trust exhibited to this point to reach this historic agreement. It will form the foundation of our relationship going forward. The University is pleased at the expansion of our relationship with the UAW, and the UAW is excited about its enhanced relationship with one of the most innovative global private teaching and research universities (New York University and UAW, 2013).

After an election was held, in which the graduate assistants voted overwhelmingly in favor of UAW representation, a new six-year contract between NYU and the UAW was negotiated and ratified in 2015 (Asher-Schapiro, 2015). Voluntary recognition, however, is no panacea because an institution like NYU retains the option to withdraw recognition after a contract terminates (Herbert, 2017).

One year later in Columbia University (2016), the NLRB reversed Brown University as well as earlier precedent and found that graduate and undergraduate assistants at private institutions met the broad statutory definition of employee and the common law test for employment. In reaching the Columbia University decision, the NLRB cited "the historic flexibility of collective bargaining as a practice and its viability at public universities where graduate student assistants are represented by labor unions and among faculty members at private universities" (Columbia Univ., 2016, pp. 9-10). The Board specifically referenced the 
collective bargaining experiences at NYU and at the University of Illinois, Michigan State University, and Wayne State University (Columbia Univ., 2016, pp. 9-11).

The Columbia University decision was quickly embraced by graduate and undergraduate student employees on private sector campuses in support of their efforts to unionize, which has resulted in the certification or the voluntary recognition of unions leading to bargaining and first contracts. On other campuses, representation petitions involving student employees have been withdrawn following certifications or after votes against unionization.

In Table 2, we list the 30 questions of representation that arose following the Columbia University decision, which involved over 26,000 student employees at private sector higher education institutions and the outcomes of those representation efforts. It demonstrates that since the 2016 NLRB decision, there have been four new first contracts negotiated at private institutions with negotiations proceeding at an additional four schools. Student employees voted against unionization in only four elections, reinforcing the democratic nature of the unionization process.

Table 2

Questions of Representation and Outcomes Since 2016 at Private Institutions+

\begin{tabular}{clcc}
\hline State & \multicolumn{1}{c}{ Institution } & National Union & Outcome \\
\hline DC & American University & SEIU & Certification and First Contract \\
MA & Brandeis University & SEIU & Certification and First Contract \\
MA & Tufts University & SEIU & Certification and First Contract \\
NY & New School & UAW & Certification and First Contract \\
MA & Harvard University & UAW & Certification and Bargaining \\
NY & Columbia University & UAW & Certification and Bargaining \\
DC & Georgetown University & AFT & Voluntary Recognition and \\
MA & Brown University & & Bargaining \\
IL & University of Chicago \pm & AFT & Voluntary Recognition and \\
IL & Loyola University & IBT & Certification and Refusal to Bargain \\
IL & University of Chicago & SEIU & Certification and Refusal to Bargain \\
MA & Boston College & AAP-AFT & Withdrawal after Certification \\
CT & Yale University $*$ & UAW & Withdrawal after Certification
\end{tabular}




\begin{tabular}{|c|c|c|c|}
\hline State & Institution & National Union & Outcome \\
\hline $\mathrm{CT}$ & Yale University * & UNITE-HERE & Withdrawal after Certification \\
\hline $\mathrm{CT}$ & Yale University * & UNITE-HERE & Withdrawal after Certification \\
\hline $\mathrm{CT}$ & Yale University * & UNITE-HERE & Withdrawal after Certification \\
\hline $\mathrm{CT}$ & Yale University * & UNITE-HERE & Withdrawal after Certification \\
\hline CT & Yale University * & UNITE-HERE & Withdrawal after Certification \\
\hline $\mathrm{CT}$ & Yale University * & UNITE-HERE & Withdrawal after Certification \\
\hline $\mathrm{CT}$ & Yale University * & UNITE-HERE & Withdrawal after Certification \\
\hline IA & Grinnell College & $\begin{array}{l}\text { Unaffiliated } \\
\text { Union }\end{array}$ & Withdrawal after Certification \\
\hline OR & Reed College & $\begin{array}{l}\text { Unaffiliated } \\
\text { Union }\end{array}$ & Withdrawal after Certification \\
\hline $\mathrm{CT}$ & Yale University * & UNITE-HERE & $\begin{array}{c}\text { Dismissal after Vote Against } \\
\text { Representation }\end{array}$ \\
\hline MI & Washington University & SEIU & $\begin{array}{c}\text { Withdrawal after Vote Against } \\
\text { Representation }\end{array}$ \\
\hline $\mathrm{NC}$ & Duke University & SEIU & $\begin{array}{c}\text { Withdrawal after Vote Against } \\
\text { Representation }\end{array}$ \\
\hline NY & Cornell University & AFT & $\begin{array}{c}\text { Dismissal after Vote Against } \\
\text { Representation }\end{array}$ \\
\hline $\mathrm{CT}$ & Yale University & UNITE-HERE & Withdrawal prior to Election \\
\hline PA & $\begin{array}{l}\text { University of } \\
\text { Pennsylvania }\end{array}$ & AFT & Withdrawal prior to Election \\
\hline $\mathrm{DC}$ & $\begin{array}{l}\text { George Washington } \\
\text { University }\end{array}$ & SEIU & Withdrawal prior to Election \\
\hline IA & Grinnell College & $\begin{array}{c}\text { Unaffiliated } \\
\text { Union }\end{array}$ & Withdrawn prior to Election \\
\hline
\end{tabular}

Note: + Each outcome with a certification or a voluntary recognition followed an election where the student employees voted in favor of union representation.

\pm At the University of Chicago, an NLRB decision finding that the university engaged in unfair labor practice by refusing to bargain with the union representing the library student employees was enforced by a recent federal appellate court decision. See, Univ. of Chicago, enforced, Univ. of Chicago v. NLRB (2019). At Yale University, UNITE-HERE sought to organize graduate assistants at 10 separate departments. However, precedent for the certification of such microunits was overturned by the NLRB in PCC Structurals Inc (2017). 


\section{Precedent and Experience from the States and Canadian Provinces}

In general, the NLRB has largely ignored the wealth of precedent and experience relating to collective bargaining for student employees from States and Canadian provinces over the past half-century. Active avoidance of these sources of relevant precedent and experience continues in the NPRM, which limits its discussion to NLRB precedent.

Consideration of the experiences across the entire higher education industry including public and private institutions is fully consistent with the statement in the NPRM that "rulemaking is preferable to adjudication with respect to the industry-wide determination whether students" who work on campuses are employees for purposes of collective bargaining (emphasis added) (Jurisdiction-Nonemployee Status of University and College Students Working in Connection with Their Studies, 2019). It is self-evident that an industry-wide determination cannot be made without an industry-wide factual and legal foundation. This is particularly true when IPEDs data establishes that close to $80 \%$ of the graduate assistants employed in the higher education industry work at public institutions.

Since 1969, a large body of state law and Canadian provincial precedent has developed concerning the right of graduate assistants and other student employees to unionize and engage in collective bargaining at public institutions. This precedent, while not binding, is persuasive authority that the NLRB should carefully review and address during its rulemaking process. Unlike NLRB case law, public sector administrative case law has been largely stable with few reversals on the question of the employee status of student workers even though the composition of public sector labor relations agencies is subject to a similar nomination and confirmation process as the NLRB. The relative stability of public sector administrative precedent contradicts the Supreme Court's assertion in Janus v. AFSCME Council 31 (2018) that public sector collective bargaining is inherently political.

Experience with unionization and collective bargaining in the public sector with respect to graduate assistants began in 1968. In that year, during hotly contested representation cases at the State University of New York (SUNY) before the New York State Public Employment Relations Board (NYPERB) SUNY, American Federation of Teachers (AFT) locals, and AAUP stipulated to exclude graduate assistants without academic rank from a bargaining unit of professors and other professionals (State of New York [State University of New York]), 1968, pp. 1919-1921). During a colloquy with the hearing officer, however, AFT's Irving Kugler added a caveat that the stipulation would not prejudice graduate assistants to unionize in a future proceeding (State of New York [State University of New York]), 1968, p. 1920). 
The following year, NYPERB certified UFCT, an AFT affiliate, to represent a bargaining unit of "members of the temporary instructional staff classified as lecturer and teaching assistant" employed by the City University of New York (CUNY) (Bd. of Higher Ed. of the City Univ. of New York, 1969). ${ }^{12}$ The CUNY By-Laws described teaching assistants as being "selected on the basis of their potentialities as scholars and teachers; in order to encourage advanced study, they shall be assigned a service load of not more than half the normal load for the functions which they perform" (Bd. of Higher Ed. of the City Univ. of New York, 1968). At the time, lecturers were predominant in the bargaining unit because " $(\mathrm{t})$ he utilization of the teacher assistant was just coming into practice at CUNY as a result of CUNY's newly instituted graduate (Ph.D.) programs" (Mintz, 1979, p. 52).

In the same 1969 NYPERB order, another organization, the Legislative Conference of the City University of New York (LC), was certified to represent a unit of tenured and tenure-track professors, research assistants, research associates, and other professionals working at CUNY (Bd. of Higher Ed. of the City Univ. of New York, 1968, 1969). The CUNY By-Laws made the research assistant position a temporary appointment and required college graduation, postgraduate training and experience satisfactory to the department chairman and the college president. A research associate was a position that participated "in the academic research projects conducted in connection with the doctoral programs of the City University" (Bd. of Higher Ed. of the City Univ. of New York, 1968).

In March 1972, the UFCT and LC merged to form the Professional Staff Congress (PSC), which was voluntarily recognized by CUNY a few months later as the exclusive representative for a combined unit that included faculty, lecturers, teaching assistants, research assistants and others (Mintz, 1979, pp. 79-80). PSC representation of a bargaining unit with faculty, graduate teaching and research assistants, and other professionals has continued until the present day.

In 1969, a collective bargaining relationship for approximately 1,900 teaching assistants was established when the University of Wisconsin-Madison voluntarily recognized the Teachers' Assistants Association (TAA). The organizing effort "was a natural outgrowth of the nationwide movement toward collective bargaining in secondary education" (Feinsinger \& Roe, 1971, pp. 229-230). The unionization effort followed a 1968 university report, which found that the number of teaching assistants on campus had increased by $155 \%$ over the prior decade with teaching assistants responsible for three-quarters of the instructional hours in the College of Letters and Science (Feinsinger \& Roe, 1971, p. 242).

\footnotetext{
${ }^{12}$ See also, Board of Higher Education of the City of New York (1968).
} 
Stanley Aronowitz has observed that the TAA's formation "prefigured a growing feeling of unease and even anger shared by many graduate students, then and now, a feeling that the encroaching multiversity concept -- according to which only the research professor deserves the time to perform the work of knowledge production - had reached graduate education" (Aronowitz, 1997, p. 187). The TAA's radical critique of higher education, which underlined the union movement at the University of Wisconsin-Madison, is exemplified in the following excerpt from a 1969 TAA newsletter:

Ultimately, our union exists because our community of the knowledge-industry, like in all other aspects of the American economy, wealth and power are concentrated in the hands of a few non-workers. The Administration is a management which has manipulated the University not for the well-being of teaching assistants, or students, or secretaries, or janitors, but rather for the commercial interests of a capitalistic state. A situation which creates an underprivileged mass ruled by an over-privileged minority has a built-in dialectic destined to reach confrontation. The TAA is the organization leading TAs in their demand for decision-making power no less than financial rights too long denied them (TAA Newsletter, quoted in Feinsinger and Roe, 1971, p. 241).

Similar criticisms concerning the corporatization of higher education have remained at the core of the graduate assistant unionization movement over the past half-century. ${ }^{13}$ At the same time, workplace and economic conditions, along with job prospects, constitute central concerns in organizing campaigns and collective bargaining for graduate assistants (Julius \& Gumport, 2003).

Voluntary recognition at the University of Wisconsin-Madison was the only means available to the TAA to attain negotiations because Wisconsin's public sector collective bargaining law was inapplicable to teaching assistants (Christenson, 1971, pp. 210-211). ${ }^{14}$ As a result of that legal void, the university and TAA had to resolve issues normally within the jurisdiction of a labor relations agency: the procedure for determining whether the union represented a majority of the teaching assistants, the scope of bargaining, and the means of conflict resolution and enforcement (Christenson, 1971, pp. 212-213).

Negotiations between the university and the TAA led to a written contract, signed on April 17, 1970. The agreement was reached only after an impasse in negotiations, a strike, and

\footnotetext{
${ }^{13}$ See, Robin \& Stephens (1996), Quinn Johnson \& Entin (2000), Lafer (2003), and Rhoads \& Rhoades (2005).

${ }^{14}$ The negotiated agreement that led to the university’s recognition of TAA is reprinted in Feinsinger \& Roe (1971, pp. 250-51).
} 
successful mediation (Christenson, 1971, p. 210; Feinsinger \& Roe, 1971, pp. 253-255). The 1970 contract at the University of Wisconsin-Madison was the first collective bargaining agreement for graduate teaching assistants in the United States. ${ }^{15}$ Later, we examine the terms of that 1970 agreement and compare it with the provisions in contemporary contracts for student workers in higher education.

The observations of administrator Arlen Chrisetenson from the University of WisconsinMadison, who participated in the bargaining leading to voluntary recognition of the TAA and the first contract, is relevant to the NLRB's proposal to exclude student employees from NLRA coverage.

In his 1971 article, Chrisetenson stated that "(t)he experience of collective bargaining between the University and the TAA demonstrates the importance of legislation defining and regulating such a relationship" (Christenson, 1971, p. 225). Further, he observed that:

The TAA experience points up the desirability of explicit collective bargaining legislation where the group involved in the bargaining is made up of teachers. The subjects relating to a teacher's employment are so various that endless disputes concerning the scope of the duty to bargaining are inevitable. A collective bargaining statute which squarely meets such issues as whether teachers may bargain over course content, the school calendar, size of classes, choice of textbooks, and degree requirements would make the task of teachers and administrators immeasurably easier. This is not to say that any statute could resolve all of these and other issues to the satisfaction of all parties. Nor is it to say that a statute, even the most carefully drawn, can prevent disputes over the negotiability of various issues. A statute can, however, reduce the frequency of conflict and, more importantly, provide an administrative forum for resolving disputes (Christenson, 1971, p. 226).

In the early 1970s, Rutgers University, teaching assistants began to be represented in a bargaining unit with faculty following voluntary recognition of the American Association of University Professors (AAUP) (Clemens, 2015, p. 65).

The earliest known certification of a union to represent student food service workers on campus was issued on April 28, 1970 by the Oregon Public Employe Relations Board for a bargaining unit at the University of Oregon. Two years later, a certification was issued by the same agency for a union to represent the following student employee unit:

\footnotetext{
${ }^{15}$ The collective bargaining relationship for teaching assistants at the University of Wisconsin-Madison ended 41 years later following enactment of the 2011 Wisconsin Act 10, also known as the Wisconsin Budget Repair Bill.
} 
All part-time, unclassified student employes enrolled for eight (8) or more credit hours who are not represented by the Graduate Student Association and who are employed in the Food Service Section of Erb Memorial Union and the Food Service Section of the University Housing Department (Oregon Employe Relations Bd., 1972).

The question of whether graduate assistants are employees for purposes of collective bargaining has been resolved as a matter of state constitutional law by appellate court decisions in two states: Florida and Missouri. The decisions reinforce the important role that state constitutions can play in setting affirmative labor rights.

In 1982, the District Court of Appeals of Florida ruled that graduate assistants working at the University of Florida and at the University of South Florida were employees protected by the Florida State Constitution's public sector collective bargaining provision. In its decision, the Florida appellate court ruled that a 1981 amendment to the Florida Public Employees Relations Act to exclude graduate assistants was unconstitutional. ${ }^{16}$ Last year, the Missouri Court of Appeals, Western District, held that graduate assistants employed at the University of Missouri were employees and had the right to unionize under Missouri State Constitution, Article 1, Section 29, which states that "employees shall have the right to organize and to bargain collectively through representatives of their own choosing." 17

In reaching its decision, the Missouri appellate court reasoned:

Furthermore, the undisputed facts demonstrate that graduate workers are employees under its plain and ordinary meaning as found in the dictionary. "The word 'employee' is commonly defined as 'one employed by another, usually in a position below the executive level and usually for wages,' as well as 'any worker who is under wages or salary to an employer and who is not excluded by agreement from consideration as such a worker.' " Howard, 332 S.W.3d at 780 (quoting Webster's Third New International Dictionary 743 (1993)). "To 'employ' means 'to provide a job that pays wages or a salary or with a means of earning a living.' " Id. (quoting Webster's Third New International Dictionary 743).

Graduate workers teach classes, lead discussions and lab sections, proctor and grade large lecture exams, prepare and grade lab exams, assist faculty with research and writing, and keep the library open and staffed. They perform this work for the

\footnotetext{
${ }^{16}$ See, Fla. Const. art. I, $§ 6$ and United Faculty of Florida v. Board of Regents (1982a), clarified in United Faculty of Florida, Local 1847 v. Board of Regents (1982b).

${ }^{17}$ Coalition of Graduate Workers v. Curators of University of Missouri (2019), rehearing and/or transfer denied (Aug. 27, 2019), transfer denied (Oct. 29, 2019).
} 
University under the supervision of graduate faculty, administrative staff, or principal investigators. In return for this work, the University pays them a flat stipend or hourly wage. These payments are paid as earnings and taxed at the time of payment, and the federal government regards the payments as income for tax purposes. Moreover, the University repeatedly treats graduate workers as employees through its policy and practices. The University's rules and regulations classify graduate workers as employees with specific job titles. The University requires that "[a]ny assignment of responsibilities, such as teaching a course, must be associated with fair and reasonable compensation." It includes graduate workers in its workers' compensation coverage, providing that "[a]11 academic and non-academic employees of the University, both full-time and part-time, (including student employees) are extended coverage." And finally, it requires graduate workers to complete employee training on discrimination prevention and the Family Educational Rights and Privacy Act (Coalition of Graduate Workers v. Curators of Univ. of Missouri, 2019, p. 814).

There is a plethora of other state and Canadian provincial precedent finding that students who receive compensation for their work on campus are employees for purposes of collective bargaining. Most of these administrative decisions have been issued by agencies that are members, along with the NLRB, of the Association of Labor Relations Agencies (ALRA):

\section{States:}

Michigan: Regents of the Univ. of Michigan, (Mich. Emp't Relations Comm'n 1971), aff'd_Regents of the Univ. of Michigan v. Michigan Emp't Relations Comm'n, (Mich. 1973); Michigan State Univ, (Mich. Emp't Relations Comm'n 1976); Univ. of Michigan (Mich. Emp’t Relations Comm'n 1981).

Florida: Board of Regents, State Univ. System, (Fla. Emps. Relations Comm'n 1977), aff'd Board of Regents of Florida v. Public Emps Relations Comm'n. (1979).

California: Univ. of California, (Cal. Pub. Emp't Relations Bd. 1983), aff'd, Regents of the Univ. of California v. Public Employment Relations Bd., (Cal. 1986); Regents of the Univ. of California (Cal. Pub. Emp't Relations Bd. 1989); Regents of the Univ. of California (Cal. PERB 1998); Trustees of the California State Univ. (Cal. Pub. Emp't Relations Bd. 2004).

New York: Bd. of Higher Ed of the City Univ. of New York (N.Y. Pub. Emp. Relations Bd., 1968, 1969); Faculty-Student Association of State Univ. of New York at Stony Brook, Inc. (N.Y.S. Labor Relations Bd.1973); State of New York (State Univ. of New York) (N.Y. Pub. Emp. Relations Bd. 1991), conf'd State of New York 
(State Univ. of New York) v. New York Pub. Empl. Relations. Bd, (N.Y. App. Div. 1992).

Iowa: Univ. of Iowa/State Bd. of Regents (Iowa Pub. Emp't. Relations Bd. 1994).

Kansas: Kansas Bd. of Regents, Univ. of Kansas, (Kan. Pub. Emp. Relations Bd. 1994).

Pennsylvania: Employes of Temple Univ. of the Commonwealth Sys. of Higher Ed. (Pa. Labor Relations Bd. 2001); Univ. of Pittsburgh (Pennsylvania Pa. Labor Relations Bd. 2019).

Massachusetts: Univ. of Massachusetts, Amherst, (Mass. Labor Relations Comm'n 2001); Univ. of Massachusetts (Mass. Labor Relations Comm'n 2002); Univ. of Massachusetts, Amherst (Mass. Labor Relations Comm'n 2015).

Washington: Univ. of Washington (Wash. Pub. Emp't Relations Comm'n. 2003).

Minnesota: Univ. of Minnesota (Minn. Bureau of Mediation Servs. 2005); Minn. Stat. §179A.03(14) (2005);

Montana: Montana State Univ. (Mont. Bd. of Personnel Appeals 2011).

Oregon: Oregon State Univ. (Oregon Or. Emp't Relations Bd. 2013).

\section{Canadian Provinces:}

Newfoundland: Memorial Univ. of Newfoundland (Nfld. Labour Relations Bd 2007).

Ontario: York Univ. (Ont. Labour Relations Bd. 1975); Carleton Univ. (Ont. Labour Relations Bd. 1978); York Univ. (Ont. Labour Relations Bd. 1981); Univ. of Western Ontario (Ont. Labour Relations Bd. 2007).

In 2019, Illinois amended the Illinois Educational Labor Relations Act to eliminate the exclusion of graduate assistants from the right to collectively bargain (Illinois Public Act of 2019). In contrast, Ohio continues to statutorily exclude graduate assistants, interns and residents, and other students working as part-time public employees from the definition of public employee under that state's collective bargaining law (Univ. Hospital, Univ. of Cincinnati Coll. of Medicine v. State Employment Relations Bd., 1992; Ohio Rev. Code Ann., 2015). 


\section{Empirical Evidence from Collective Bargaining in the United States}

\section{Terms of Current Collective Bargaining Agreements}

Precedent over the past half-century finding graduate assistants and other student employees to be entitled to unionize and engage in collective bargaining has resulted in empirical evidence that the NLRB should consider when determining the relationship between higher education institutions and student employees; principally, the terms of existing collective bargaining agreements at private and public institutions. These negotiated provisions are the clearest expression of both the relationship between the institutions and the represented employees as well as the compromises inherent in collective bargaining in order to reach an agreement.

In Table 3, we identify 42 public and private institutions with current contracts that cover an aggregate of more than 68,000 graduate and/or undergraduate employees along with a link to each contract. The number of current contracts is over double the number identified in 2002 by Julius and Gumport (2003). We have not included in Table 3 agreements applicable to interns and residents working at higher education medical institutions because the status of those employees under the NLRA does not appear to be at-issue under the proposed rule (Boston Med. Ctr. Corp., 1999). We note, however, that the most recently certified union of interns and residents in higher education was at Oregon Health \& Science University on November 5, 2019 (Oregon Health \& Science Univ. 2019).

Our research has found that there are an additional 12,848 graduate and undergraduate assistants in eight new collective bargaining units without first contracts at the time of writing, six at private institutions and two at public institutions: Georgetown University, Loyola University Chicago, University of Chicago, Harvard University, Columbia University, Brown University, Illinois State University, and Southern Illinois University - Edwardsville.

\section{Table 3}

Institutions with Current Collective Bargaining Agreements and Links

\begin{tabular}{lll}
\hline State & \multicolumn{1}{c}{ Institution } & Link to Collective Bargaining Agreement \\
\hline CA & California State University $\dagger$ & $\underline{\text { http://silo.hunter.cuny.edu/LoaUVKSu }}$ \\
CA & University of California $\dagger$ & $\underline{\text { http://silo.hunter.cuny.edu/zjKpsphJ }}$ \\
CT & University of Connecticut & $\underline{\text { http://silo.hunter.cuny.edu/krjU6u8P }}$ \\
DC & American University * & $\underline{\text { http://silo.hunter.cuny.edu/nEcijcbc }}$ \\
FL & Florida A\&M University & $\underline{\text { http://silo.hunter.cuny.edu/tjgjdPrA }}$
\end{tabular}




\begin{tabular}{|c|c|c|}
\hline State & Institution & Link to Collective Bargaining Agreement \\
\hline FL & Florida State University & http://silo.hunter.cuny.edu/RclTero \\
\hline FL & University of Florida & $\underline{\text { http://silo.hunter.cuny.edu/T7Bvtqig }}$ \\
\hline FL & University of South Florida & $\underline{\text { http://silo.hunter.cuny.edu/A6tfcIWr }}$ \\
\hline IA & University of Iowa & $\underline{\text { http://silo.hunter.cuny.edu/pM5v1zHm }}$ \\
\hline IA & Grinnell College ${ }^{*} \dagger$ & $\underline{\text { http://silo.hunter.cuny.edu/VAD7VE }}$ \\
\hline IL & Univ. of Illinois - Springfield & $\underline{\text { http://silo.hunter.cuny.edu/Ga9Sg7ye }}$ \\
\hline IL & Univ. of Illinois - Urbana-Champaign & $\underline{\text { http://silo.hunter.cuny.edu/rvlNdeeu }}$ \\
\hline IL & Southern Illinois Univ. - Carbondale & $\underline{\text { http://silo.hunter.cuny.edu/YNG85oh8 }}$ \\
\hline IL & University of Illinois - Chicago & $\underline{\text { http://silo.hunter.cuny.edu/aPj7dYFF }}$ \\
\hline KS & University of Kansas - Lawrence & $\underline{\text { http://silo.hunter.cuny.edu/TljTn1FS }}$ \\
\hline MA & University of Massachusetts - Amherst $\S$ & $\underline{\text { http://silo.hunter.cuny.edu/gsKDoL8h }}$ \\
\hline MA & University of Massachusetts - Amherst $\dagger$ & $\underline{\text { http://silo.hunter.cuny.edu/KZHmAcmN }}$ \\
\hline MA & University of Massachusetts -Boston & $\underline{\text { http://silo.hunter.cuny.edu/IaXLwei5 }}$ \\
\hline MA & University of Massachusetts - Lowell & $\underline{\text { http://silo.hunter.cuny.edu/8hpxxoju }}$ \\
\hline MA & Brandeis University * & $\underline{\text { http://silo.hunter.cuny.edu/ELzltGa4 }}$ \\
\hline MA & Tufts University * & $\underline{\text { http://silo.hunter.cuny.edu/xwyw5P5S }}$ \\
\hline MI & Central Michigan University $\S$ & $\underline{\text { http://silo.hunter.cuny.edu/G38xPxP9 }}$ \\
\hline MI & University of Michigan & $\underline{\text { http://silo.hunter.cuny.edu/ZPHpIED5 }}$ \\
\hline MI & Michigan State University & http://silo.hunter.cuny.edu/IJ2kST49 \\
\hline MI & Wayne State University & http://silo.hunter.cuny.edu/C8K8boyK \\
\hline MI & Western Michigan University & $\underline{\text { http://silo.hunter.cuny.edu/E7sSGis2 }}$ \\
\hline MT & Montana State University & $\underline{\text { http://silo.hunter.cuny.edu/1C5MKaok }}$ \\
\hline NJ & Rutgers University & $\underline{\text { http://silo.hunter.cuny.edu/ceo8i9dh }}$ \\
\hline NY & City University of New York $₫ \S$ & http://silo.hunter.cuny.edu/uzi8Qqfl \\
\hline NY & $\begin{array}{l}\text { CUNY Research Foundation, Graduate } \\
\text { Center * } \S\end{array}$ & $\underline{\text { http://silo.hunter.cuny.edu/sWioljKy }}$ \\
\hline NY & $\begin{array}{l}\text { CUNY Research Foundation, LaGuardia } \\
\text { Community College } * \S\end{array}$ & $\underline{\text { http://silo.hunter.cuny.edu/YFck9p8S }}$ \\
\hline NY & $\begin{array}{l}\text { CUNY Research Foundation, New York } \\
\text { City College of Technology * } \S\end{array}$ & $\underline{\text { http://silo.hunter.cuny.edu/5nXC9c7V }}$ \\
\hline NY & State University of New York & $\underline{\text { http://silo.hunter.cuny.edu/COPSIryT }}$ \\
\hline
\end{tabular}




\begin{tabular}{lll}
\hline State & \multicolumn{1}{c}{ Institution } & Link to Collective Bargaining Agreement \\
\hline NY & SUNY Research Foundation * $\S$ & $\underline{\text { http://silo.hunter.cuny.edu/wUpf45Kx }}$ \\
NY & New York University * & $\underline{\text { http://silo.hunter.cuny.edu/2wFYbFZp }}$ \\
NY & The New School * $\dagger$ & $\underline{\text { http://silo.hunter.cuny.edu/0Um3ac9 }}$ \\
OR & Oregon State University & $\underline{\text { http://silo.hunter.cuny.edu/ajoALBIt }}$ \\
OR & University of Oregon & $\underline{\text { http://silo.hunter.cuny.edu/gNii5m7w }}$ \\
OR & Portland State University & $\underline{\text { http://silo.hunter.cuny.edu/sRnXaZaM }}$ \\
PA & Temple University & $\underline{\text { http://silo.hunter.cuny.edu/K53qs12f }}$ \\
RI & University of Rhode Island & $\underline{\text { http://silo.hunter.cuny.edu/BKYkuJzZ }}$ \\
WA & University of Washington - Seattle & $\underline{\text { http://silo.hunter.cuny.edu/Br10Y9nA }}$ \\
\hline
\end{tabular}

Note: * Bargaining units at private sector institutions

$\uparrow$ Bargaining units with undergraduate student employees

$\$$ Bargaining units with faculty and graduate assistants

$\S$ Bargaining units with other professional and non-professional employees

In Canada, there is an equally rich history with abundant legal precedent and experience concerning collective bargaining for graduate assistants dating back to 1974. Canada had 22 graduate assistant collective bargaining relationships as of 2003, and a national union density rate of $41 \%$ among those employees (Zinni, et al., 2005; Wickens, 2008).

\section{Composition of Student Employee Bargaining Units}

In Figure 1, we analyze the 42 bargaining units with collective bargaining agreements, which can be separated into the following bargaining unit composition categories: a) graduate assistants only; b) graduate assistants and faculty; c) graduate assistants, faculty, and other professional staff; d) graduate assistants and other professional staff; e) graduate and undergraduate assistants; and f) undergraduate student employees only.

As Figure 1 demonstrates, the most common bargaining unit that includes student employees are those composed of only graduate assistants, constituting $64.3 \%$ of the units. The second most common (16.7\%) are units with graduate assistants and professional staff. The two least common bargaining unit types (2.4\%) are combined units of graduate assistants and faculty, as well as units of graduate assistants, faculty, and professional staff. The latter two types encompass the bargaining units at the CUNY and Rutgers University, the two oldest bargaining units with current contracts. 


\section{Figure 1}

Student Employee Bargaining Unit Composition

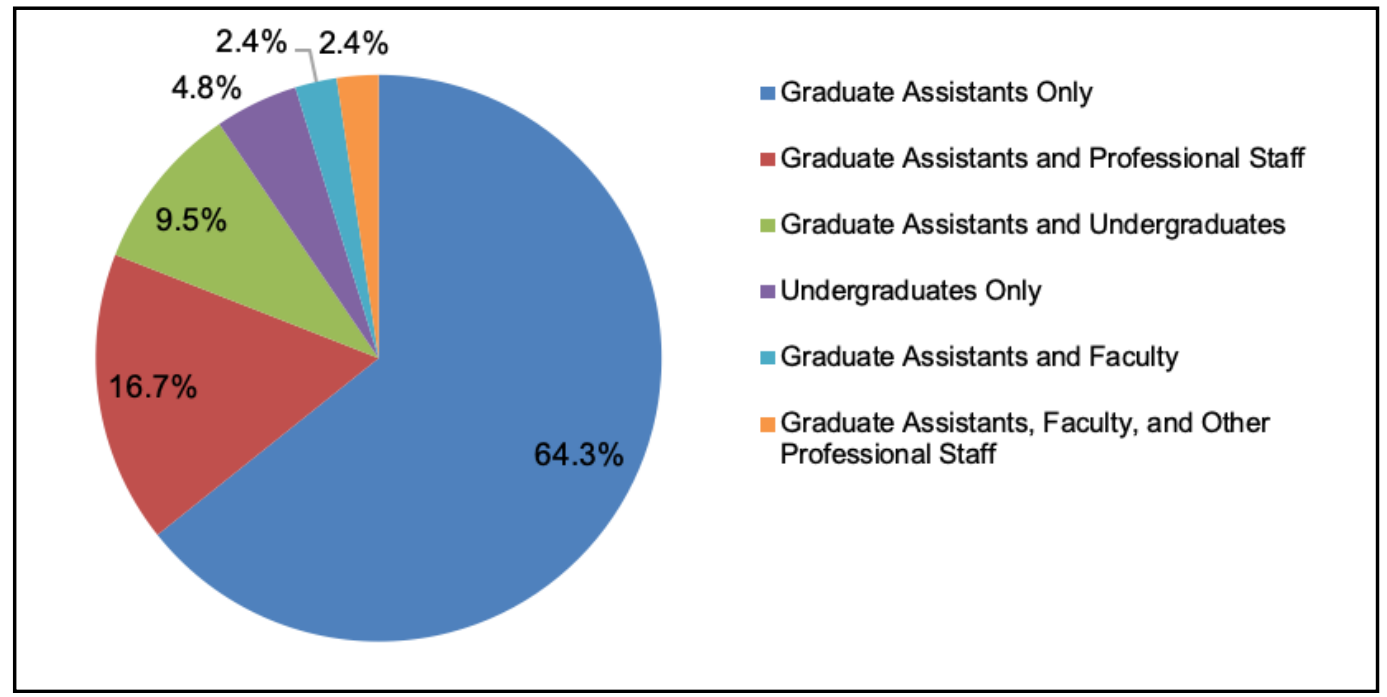

\section{Common Provisions in Current Collective Bargaining Agreements}

Two issues have permeated recent NLRB case law regarding whether graduate assistants and other student employees are statutory employees under the NLRA: whether the relationship between graduate assistants and student employees with their institutions are primarily educational in nature, and whether collective bargaining would impair universities' ability to meet their obligations when making educational and academic decisions.

An important source of information directly pertaining to both issues is the negotiated provisions in the 42 collective bargaining agreements currently in effect. These agreements constitute direct empirical evidence concerning the actual terms and conditions of represented student employees as well as the nature of the economic relationship they have with institutions of higher education. Moreover, the contract articles address policy issues raised in the NPRM including managerial control over education policies and questions of academic freedom.

Figure 2 is a chart displaying the frequency of 20 common specific terms and conditions of employment we have identified in the 42 current agreements. 


\section{Figure 2}

Percentage of 20 Specific Terms and Conditions in 42 Current Contracts

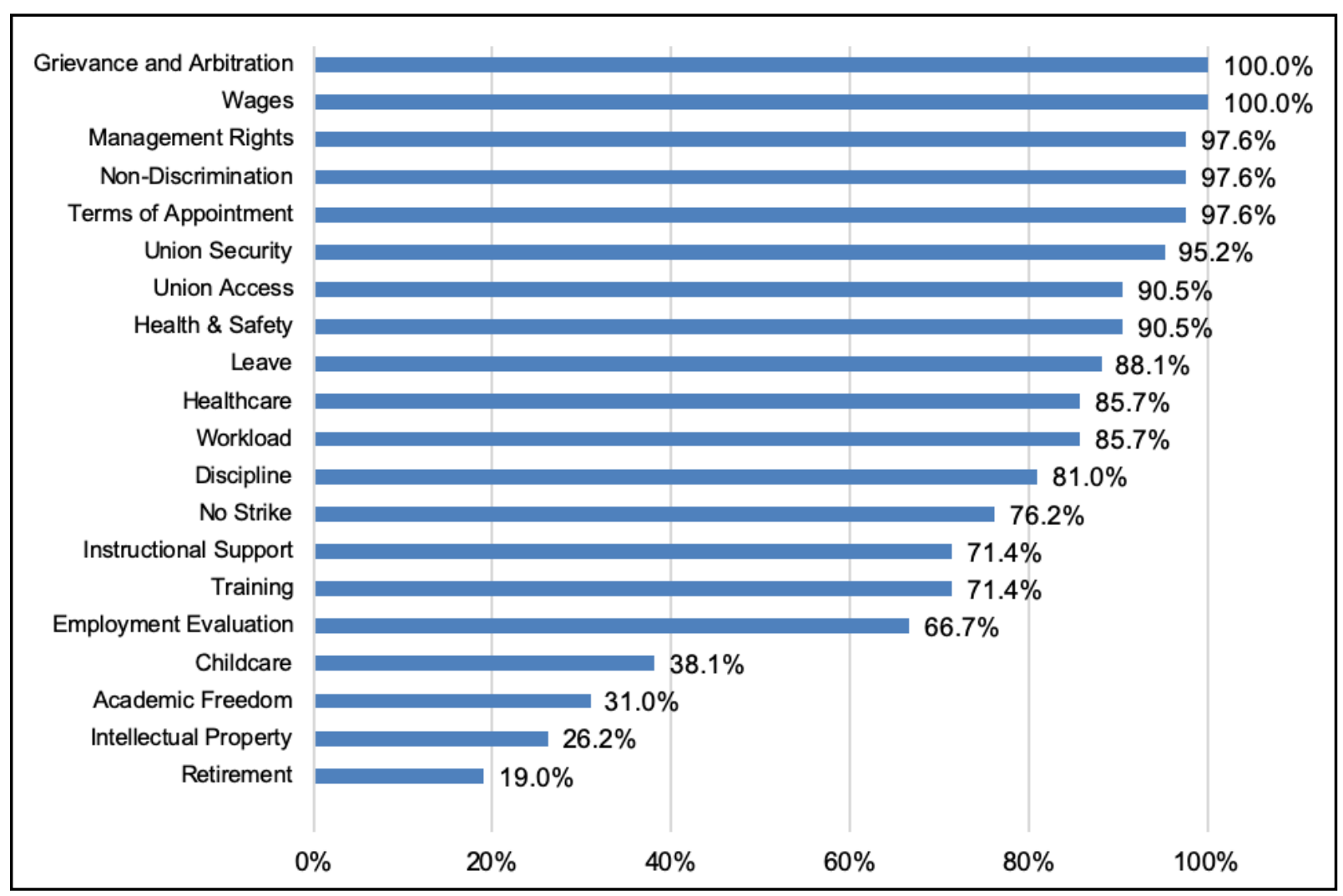

The most common provisions included in the current contracts (100\%) address wages and grievance-arbitration procedures. The next most common provisions are non-discrimination and terms of appointment clauses, which are found in 41 of the agreements (97.6\%). Closely relevant to the NLRB's rulemaking process, 40 of the contracts we examined contained management rights clauses. These clauses establish clearly the rights of the university in making academic decisions and should by themselves cast serious doubts on concerns raised by the NLRB about collective bargaining leading to graduate assistants and other students impairing the ability of universities to meet their educational obligations.

One such example of a management rights clause is contained within the following sample provision in the American University-SEIU contract:

\section{ARTICLE 2 - MANAGEMENT FUNCTIONS}

All management functions, rights, and prerogatives, written or unwritten, which have not been expressly modified or restricted by a specific provision of this Agreement, are retained and vested exclusively in Management and may be exercised by Management at its sole discretion. Such management functions, rights, and 
prerogatives include, but are not limited to, all rights and prerogatives granted by applicable law; the right to generally determine and effect American University's mission, programs, objectives, activities, resources, and priorities; to establish and administer procedures, rules and regulations, and direct and control American University operations; to alter, extend or discontinue existing equipment, facilities, and location of operations; to determine or modify the number, qualifications, scheduling, responsibilities and assignment of students and employees; to establish, maintain, modify or enforce standards of performance, conduct, order and safety; to evaluate, determine the content of evaluations, and determine the processes and criteria by which students' and employees' performance is evaluated; to establish and require students and employees to observe American University rules and regulations; to discipline or dismiss students and employees; to establish or modify the academic calendars, including holidays and holiday scheduling; to assign work locations; to schedule hours of work; to recruit, hire or transfer; to determine how and when and by whom instruction is delivered; to determine all matters relating to student and employee hiring, retention, and student admissions; to introduce new methods of instruction; to subcontract all or any portion of any operations; and to exercise sole authority on all decisions involving academic matters. Decisions regarding the recipients of financial aid and the terms of that aid, the work assignments provided, the work to be completed, and evaluation of the academic performance of the work assigned involve academic judgment and shall be made at the sole discretion of Management. Decisions regarding who is taught, what is taught, how it is taught and who does the teaching involve academic judgment and shall be made at the sole discretion of Management. Management, in not exercising any function hereby reserved to it in this Article 2, or in exercising any such function in a particular way, will not be deemed to have waived its right to exercise such function or preclude Management from exercising the same in some other way. No action taken by American University with respect to a management or academic right shall be subject to the grievance procedure or collateral suit unless the exercise thereof violates an express written provision of this Agreement.

Further, over $90 \%$ of the 42 agreements address union security (40), health and safety (38), union access (38), while no-strike clauses are included in over three-quarters of the agreements (32). More than $80 \%$ of the contracts have provisions concerning employee leave (37), health care benefits (39), workload (36), and workplace discipline (35). More than $70 \%$ of the agreements contain provisions for instructional support (30), including office space, supplies, and access to printing, as well as training provisions (30) that grant employees professionalization opportunities. Over $65 \%$ of the negotiated agreements have terms applicable 
to employment evaluations by the university (28), and eight contracts include retirement as a subject. These agreements taken together demonstrate a clear functional economic relationship between student workers and the universities that employ them.

Nearly a third of the agreements (30\%) also include provisions for academic freedom, while intellectual property is a negotiated topic in over a quarter of the contracts. With respect to academic freedom, examples exist in both new and old agreements across private and public sector institutions: Article 5 of the Brandeis University-SEIU contract, Article II of the Rutgers University-AAUP contract, and Article XIV of the University of Rhode Island-NEA contract. One such example comes from the City University of New York-PSC contract, which states:

CUNY and the PSC seek to maintain and encourage, in accordance with law, full freedom of inquiry, teaching, research and publication of results, the parties subscribe to Academic Freedom for faculty members. The principles of Academic Freedom are recognized as applicable to other members of the Instructional Staff, to the extent that their duties include teaching, research and publication of results, the selection of library or other educational materials or the formation of academic policy.

The existence of these agreements demonstrates the stability of graduate student collective bargaining relations, as well as a clear delineation of the academic and educational obligations of universities and a demonstration of the capacity of these institutions to establish functional economic relationships with their student employees. Examples of long-term stability are further evidenced by agreements with substantial historical lineages, such as the contracts at CUNY and Rutgers University.

To highlight the consistencies and changes concerning the terms of contracts applicable to student employees over the past half-century it is useful to compare the 1970 TAA-University of Wisconsin at Madison contract, the first collective bargaining agreement for graduate teaching assistants in the United States, with the 10 most recent student employee contracts reached on other campuses since 2012.

Figure 3 provides a list of provisions included in the TAA's first contract from the list of 20 specific terms and conditions set forth in Figure 5. Of the 20 specific terms and conditions in Figure 3, the initial 1970 TAA agreement contains 14. 


\section{Figure 3}

20 Specific Terms and Conditions Included in the University of Wisconsin-TAA Agreement

- Terms of Appointment

- Compensation

- Healthcare

- No Strike

- Non-Discrimination

- Health and Safety

- Grievance and Arbitration

- Performance Evaluation

- Management Rights

- Discipline

- Union Security

- Workload

- Union Access

- Instructional Support

The economic relationship between the university and the teaching assistants at the University of Wisconsin-Madison is evidenced by the contract's inclusion of traditional subjects of collective bargaining common in other contracts applicable to student employees: discipline, health insurance, sick leave, evaluations, probation, workload, transfers, antidiscrimination, and grievance-arbitration (see Figure 3). The TAA agreement also includes a management rights clause, albeit located in a section entitled "Anti-Democratic, Anti-Union Clauses," which also included a no-strike provision.

In contrast to currently existing contracts, the TAA agreement permitted departmental bargaining of supplemental agreements in departments where a majority of the graduate assistants were TAA members. The organizing efforts by Stanford University physics department research assistants in the early 1970s and the 2016-2018 departmental-based organizing of graduate assistants at Yale University sought, in essence, what the TAA agreement permitted: bargaining by department. Lastly, the TAA agreement included language granting graduate assistants input in departmental educational planning including course offerings, with the caveat that "such mechanisms...shall not infringe upon the ultimate responsibility of the faculty for curriculum and course conduct" (University of Wisconsin-Madison and the Teaching Assistants Association, 1970). 
We now compare in Figure 4 the 1970 first contract at the University of WisconsinMadison with the provisions in the 10 first contracts reached since 2012 involving student employees. ${ }^{18}$

\section{Figure 4}

Percentage of 20 Specific Terms and Conditions in 10 Recent First Contracts Applicable to Student Employees

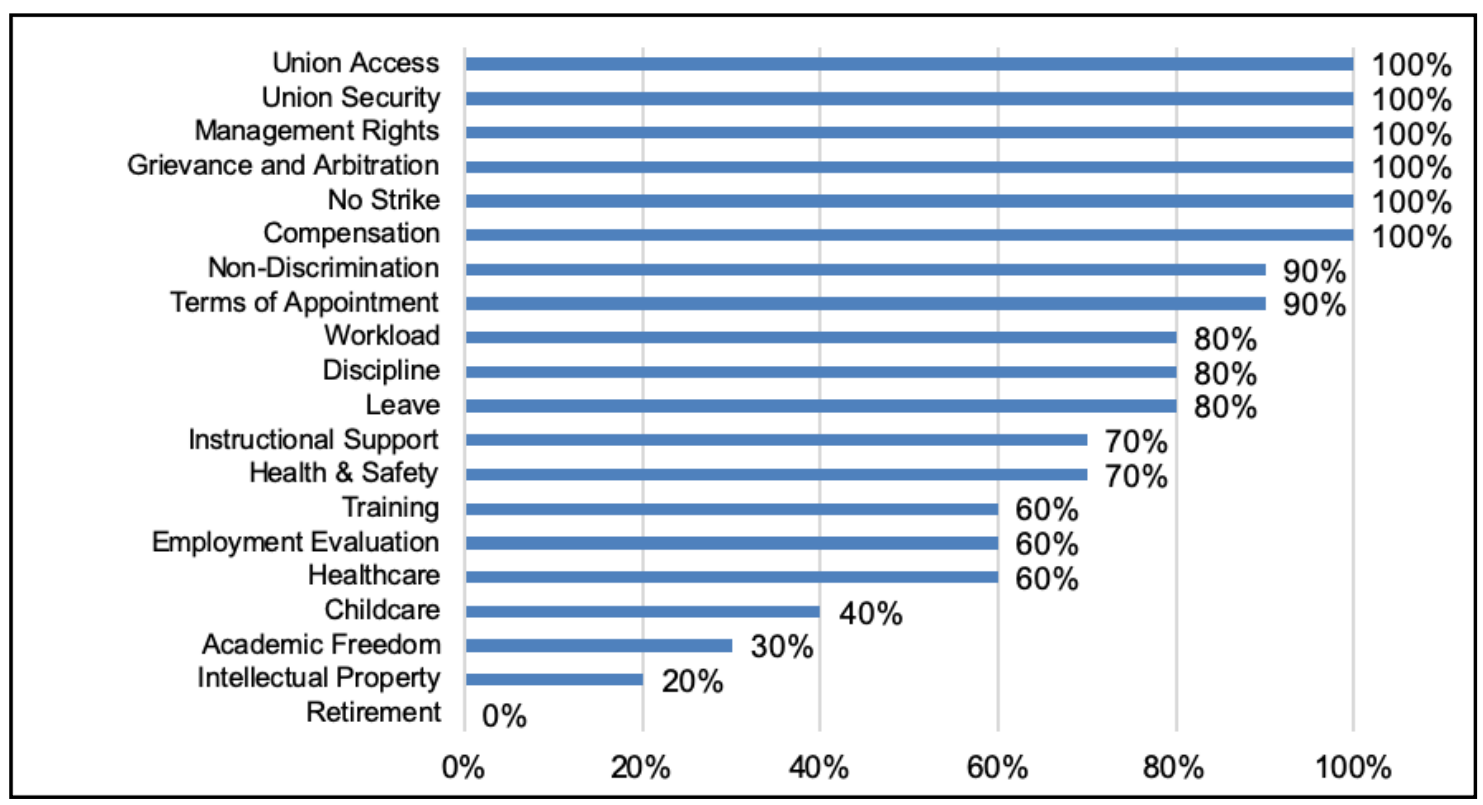

Comparing the TAA agreement against the frequency of the provisions outlined in Figure 7 illuminates the degree to which student employee collective bargaining has changed over the past 50 years, principally in the sort of provisions that were once absent and have now become commonplace. First, the TAA agreement lacks language around compensation in the form of wages or salaries. Such provisions are included in $100 \%$ of the current collective bargaining agreements for student employees. Instead, under Section V. Job Rights, the agreement guarantees student employees "financial support" in the form of employment as a "fellow, R.A., P.A., or trainee." Second, the TAA agreement did not include provisions for leave, training and professional development, child care provisions, or academic freedom. Yet, $80 \%$ of all recent student employee contracts now include a leave provision, two-thirds include provisions for training and professional development, $40 \%$ include child care provisions, and approximately one-third have language that negotiates academic freedom for student employees.

\footnotetext{
${ }^{18}$ The 10 agreements were reached at American University, Brandeis University, Tufts University, The New School, University of Massachusetts - Amherst, Portland State University, University of Connecticut, Grinnell College, Montana State University, and Oregon State University.
} 
Taken together, the first 50 years of graduate student collective bargaining since the 1970 TAA agreement has been a period of considerable stability, particularly in the public sector. Comparing the TAA agreement with the 10 most recent student employee agreements, longstanding unionization has resulted in remarkably similar contracts over time, with provisions designed to clearly and consistently demarcate the academic and educational obligations of universities. Simultaneously, the comparison demonstrates the significant degree to which graduate assistants are intimately intertwined into the economic functions of the modern university. This is evidenced by the inclusion and increasing regularity of provisions for leave, childcare, and training, as well as the ubiquity of provisions for compensation in the form of wages as opposed to "support." The above comparison underscores the myriad ways that the position of the graduate assistant in the $21^{\text {st }}$ century is an occupation consistent with BLS's categorization (Bureau of Labor Statistics, U.S. Department of Labor 2018). As the modern university continues to change, the central and increasing work performed by graduate assistants brings with it a different set of needs for the current generation of student employees, unique to their roles as workers.

\section{Conclusion}

This article has presented substantial information from the entire higher education industry over the past half-century that can aid the NLRB as it revisits the question of whether graduate assistants and other student employees are statutory employees under Section 2(3) of the NLRA.

In its reexamination, the NLRB must go beyond rehashing arguments from prior majority and dissenting decisions to facts, data, and experience concerning unionization of student employees in the entire higher education industry. The first primary source of information comes from BLS and NCES that recognize the position of a graduate assistant is an occupation, distinct from the status of a graduate student. The second source is the terms of the current 42 collective bargaining agreements at private and public colleges and universities demonstrating the economic relationship between the institutions and their student employees. Another central source is the half-century of history, experience, and legal precedent from States and Canadian provinces that have been largely overlooked in prior NLRB adjudicatory cases.

In addition, the NLRB should carefully consider the 1971 judgment of University of Wisconsin-Madison administrator Arlen Chrisetenson who emphasized, based on his experience with TAA, the importance and relevance of collective bargaining legislation to help avoid unnecessary labor disputes on campus. 
The failure of the NLRB to closely analyze and address the decades of relevant collective bargaining history, precedent, and contracts, and to directly solicit testimony from those who have negotiated and administered the contracts, will undermine the validity and legitimacy of any final rule. 


\section{References}

\section{Books and Articles}

Antonyan, D. (2020) Sanders's new senate bill could protect graduate student workers' employee rights from proposed NLRB ruling, experts say, Harvard Crimson Retrieved from https://www.thecrimson.com/article/2020/2/4/sanders-graduate-unionization-bill/

Aronowitz, S. (1997). Academic unionism and the future of higher education. In C. Nelson (Ed.), Will teach for food: Academic labor in crisis, (p.181-217). Minneapolis: University of Minnesota Press.

Asher-Schapiro, A. (2015, March 11). NYU's graduate student union just won a historic contract. The Nation. Retrieved from https://www.thenation.com/article/archive/nyusgraduate-student-union-just-won-historic-contract/

Berry, J. \& Savarese, M. (2012). Directory of U.S. faculty contracts and bargaining agents in institutions of higher education, (No. 2), New York: National Center for the Study of Collective Bargaining in Higher Education and the Professions, Hunter College, City University of New York.

Buchsbaum, J., Gorfinkel, E., Baza, A., Palm, M., Lawler, T., \& Lewis, P. (2006). Interview: student strike organizers at NYU. Cinema Journal, 45(4), 86-97.

Bureau of Labor Statistics, U.S. Department of Labor (2018). Standard Occupational Classification System, Retrieved from: https://www.bls.gov/soc/2018/home.htm

Christenson, A. (1971). Collective bargaining in a university: The University of Wisconsin and the Teaching Assistants Association. Wisconsin Law Review, 1, 210- 228.

Clemens, P.G. (2015). Rutgers since 1945: A history of the State University of New Jersey. New Brunswick: Rutgers University Press.

DeCew, J. W. (2003). Unionization in the academy: Visions and realities. New York: Rowman \& Littlefield Publishers.

Estreicher, S. (1985). Policy oscillation at the labor board: A plea for rulemaking. Administrative Law. Review, 37(2), 163-181.

Feinsinger, N.P. \& Roe, E.J. (1971). The University of Wisconsin, Madison Campus - TAA Dispute of 1969-70: A case study. Wisconsin Law Review, 1, pp 229-274.

Finder, A. (2005, August 6). N.Y.U. ends negotiations with union for students, New York Times. Retrieved from https://www.nytimes.com/2005/08/06/nyregion/nyu-endsnegotiations-with-union-for-students.html/

Garden, C. (2014). Toward politically stable NLRB lawmaking: Rulemaking vs. adjudication. Emory Law Journal, 64, 1473-77.

Greenhouse, S. \& Kraminer, A. (2013, November 26). With new agreement, N.Y.U. would again recognize graduate assistants' union. New York Times. Retrieved from https://www.nytimes.com/2013/11/27/nyregion/with-new-agreement-nyu-would-againrecognize-graduate-assistants-union.html

Hafiz, H. (2017). Economic analysis of labor regulations. Wisconsin Law Review, 6, 11151188. 
Herbert, W. A. (2017). The history books tell it? Collective bargaining in the 1940s. Journal of Collective Bargaining in the Academy, 9.

Herbert, W.A. (2018). Jerome Lefkowitz. A pragmatic intellect and major figure in Taylor Law history. Hofstra Labor \& Employment Law Journal, 36, 29-54.

Herbert, W. A., \& Apkarian, J. (in press). You've been with the professors: An examination of higher education work stoppage data, past and present. Employee Rights and Employment Policy Journal, 23(2).

Holmes, O.W. (1881/2017). The common law. Clark: The Lawbook Exchange.

Hyman. L. (2018). Temp: How American work, American business, and the American dream became temporary. New York: Viking Press.

Julius, D. J., \& Gumport, P. J. (2003). Graduate student unionization: Catalysts and consequences. The Review of Higher Education, 26(2), 187-216.

Kanu, H.A. (2020, 25 February). NLRB Issues New Joint Employer Rule Requiring Direct Control. Bloomberg Law. Retrieved from https://news.bloomberglaw.com/daily-laborreport/nlrb-issues-new-joint-employer-rule-requiring-direct-control

Lafer, G. (2003). Graduate student unions: Organizing in a changed academic economy. Labor Studies Journal, 28(2), 25-34.

McNicholas, C., Poydock, M., \& Wolfe, J. (2019). Graduate student workers' rights to unionize are threatened by trump administration proposal. Washington, D.C.: Economic Policy Institute. Retrieved from https://www.epi.org/publication/graduatestudent-workers-rights-to-unionize/

Mintz, B. (1979). Living with collective bargaining: A case study of the City University of New York. New York: National Center for the Study of Collective Bargaining in Higher Education, Baruch College, City University of New York.

National Labor Relations Board. (2019, May 22). NLRB rulemaking agenda announced [Press Release]. Retrieved from https://www.nlrb.gov/news-outreach/news-story/nlrbrulemaking-agenda-announced

New York University and UAW. (2013, November 26). Joint statement of New York University and GSOC and SET, UAW [Press release]. Retrieved from https://www.nyu.edu/about/news-publications/news/2013/november/joint-statement-ofnyu-and-gsoc-and-set-uaw.html

Quinn Johnson, K., \& Entin, J. (2000). Graduate employee organizing and the corporate university. New Labor Forum 6, 99-107.

Rhoads, R.A., \& Rhoades, G. (2005). Graduate employee unionizations as a symbol of and challenge to the corporatization of U.S. research industries. The Journal of Higher Education 77(3), 243-275.

Robin, C., \& Stephens, M. (1996). Against the grain: Organizing TAs at Yale. Social Text, 49, 43-73.

Thornton C. (2013, December 16), Union again at NYU. Jacobin. Retrieved from https://www.jacobinmag.com/2013/12/union-again-at-nyu/ 
Weil, D. (2014). The fissured workplace. Cambridge: Harvard University Press.

Wickens, C.M. (2008). The organizational impact of university labor unions. Higher Education, 56(5), 545-564.

Zinni, D.M., Singh, P., \& MacLennan, A.F. (2005). An exploratory study of graduate student unions in Canada. Relations Industrielles/Industrial Relations, 60(1), 145-176.

\section{Archival Materials}

Board of Higher Education of the City University of New York. (1968, February 27). [ByLaws of the Board of Education of the City of New York] NYPERB Case File No. C0008 (174892-08, Box 56). New York State Archives, Albany, New York.

Oregon Employe Relations Board. (1972, August 8). [Agent Brown to AFSCME Council 75]. Copy in possession of authors.

State of New York (State University of New York). (1968, October 28). [Hearing transcript]. NYPERB Case Nos. C-0253, C-0260, C-0262, C-0263, C-0264, and C-0351 (1749219A, Box 3). New York State Archives, Albany, New York.

University of Wisconsin-Madison and the Teaching Assistants Association. (1970, April 7). Agreement Between the University of Wisconsin: Madison Campus and the Teaching Assistants Association (TAA). Series 0/31, Teaching Assistants Association - Arlen Christenson Papers (Box 2, Folder 11, TAA + University Bargaining Team Counter Proposals). University of Wisconsin-Madison Archives, Madison, Wisconsin.

\section{Statutes and Regulations}

Colleges and Universities, 29 C.F.R. § 103.1 (1970).

Fla. Const. art. I, § 6 .

Illinois Public Act 101-0380 (2019).

Minn. Stat. §179A.03(14) (2005).

Joint-Employer Status Under the National Labor Relations Act, 29 C.F.R. Part 103 (Adopted Feb. 26, 2020) Retrieved from: https://s3.amazonaws.com/publicinspection.federalregister.gov/2020-03373.pdf

Jurisdiction-Nonemployee Status of University and College Students Working in Connection with Their Studies, 84 Fed. Reg. 49691-01 (Proposed Sept, 23, 2019) (to be codified at 29 C.F.R. § 103).

Labor-Management Relations Act of 1947, Public Law 80-101, 61 STAT 136.

Missouri Const., art 1, § 29.

National Labor Relations Act of 1935, 29. U.S.C. § 151, et seq.

Ohio Rev. Code Ann. § 4117.01 (2015). 


\section{Court and Administrative Decisions}

Adelphi University, 195 NLRB 639 (1972).

Alstate Maintenance, LLC, 367 NLRB 68 (2019).

American Hospital Association v. National Labor Relations Board, et al, 499 U.S. 606 (1991).

Apogee Retail LLC d/b/a Unique Thrift Store, 368 NLRB 144 (2019).

Associated Builders and Contractors of Texas, Inc. v. National Labor Relations Board, 826 F.3d 215 ( $5^{\text {th }}$ Cir. 2016).

Barnard College, 204 NLRB 1134 (1973).

Board of Higher Education of the City of New York, 2 NYPERB 3056 (N.Y. Pub. Emp. Relations Bd. 1968).

Board of Higher Education of the City of New York., 2 NYPERB 3000 (N.Y. Pub. Emp. Relations Bd. 1969).

Board of Regents, State University System, 3 FPER 304 (1977), aff'd Board of Regents of Florida v. Public Employees Relations Comm'n., 368 So.2d 641 (Fla. 1st DCA 1979), cert. denied, 379 So.2d 202 (Fla.1979).

Boston Medical Center Corporation, 330 NLRB 152 (1999).

Brown University, 342 NLRB 483 (2004).

Caesars Entertainment d/b/a Rio All-Suites Hotel and Casino, 368 NLRB 143 (2019).

Carleton University, OLRB Rep. Feb. 179 (Ont. Labour Relations Bd. 1978).

Cedars-Sinai Medical Center, 223 NLRB 251 (1976).

Coalition of Graduate Workers v. Curators of University of Missouri, 585 S.W.2d 809 (Mo. Ct. App. 2019).

College of Pharmaceutical Sciences in the City of New York, 197 NLRB 959 (1972).

Cornell University, 202 NLRB 290 (1973).

Employes of Temple University of the Commonwealth System of Higher Education, 32 PPER 32164 (Pa. Labor Relations Bd. 2001).

Faculty-Student Association of State University of New York at Stony Brook, Inc., 36 NYSLRB 353 (N.Y.S. Labor Relations Bd. 1973).

Janus v. American Federation of State, County, and Municipal Employees, Council 31, 138 S. Ct. 2448 (2018).

Kansas Board of Regents, University of Kansas, PERB Case No. 75-UD-1-1992 (Kan. Pub. Emp. Relations Bd. 1994). Retrieved from: https://www.dol.ks.gov/docs/defaultsource/labor-relations-documents/db add1/75-ud-1-1992.pdf?sfvrsn=d59b8f1f_2

Leland Stanford Junior University, 214 NLRB 621 (1974).

Memorial University of Newfoundland, LRBD No. 16 (Nfld. Labour Relations Bd. 2007). 
Michigan State Univ, 1976 MERC Lab Op 73 (Mich. Emp’t Relations Comm'n. 1976).

Montana State University, LSB Case No. 1020-2011 (Mont. Bd. of Personnel Appeals, 2011)

Retrieved from https://dli.mt.gov/Portals/57/OAHDecisions/cbdec1020_2011.pdf

MV Transportation, Inc., 368 NLRB 66 (2019).

National Labor Relations Board v. Bell Aerospace Company, 416 U.S. 267 (1974).

National Labor Relations Board v. Town \& Country Electric, Inc., 516 U.S. 85 (1995).

New York University, 332 NLRB 1205 (2000).

Oregon State University, ERB Case No. UC-04-12, (Or. Emp't Relations Bd. 2013)

Retrieved from https://www.oregon.gov/erb/Documents/UC-004-12.pdf

Oregon Health \& Science University, OERB Case No. RC-009-19 (Or. Emp't Relations Bd.

2019) Retrieved from https://www.oregon.gov/erb/Documents/RC-009-19_BD-

CERT.pdf

PCC Structurals Inc., 365 NLRB 160, (2017).

Regents of the University of California, 22 PERC II 29084, (Cal. Pub. Emp. Relations Bd. 1988).

Regents of the University of California, 13 PERC II 20087 (Cal. Pub. Emp. Relations Bd. 1989).

Regents of the University of Michigan, 1971 MERC Lab Op 270 (Mich. Emp't Relations Comm'n. 1971), aff'd Regents of the University of Michigan v. Michigan Emp't Relations Comm'n., 204 N.W.2d 218 (Mich. 1973).

San Francisco Art Institute, 226 NLRB 1251 (1976).

Saga Dining Halls, Inc., 29 NYSLRB 178 (N.Y.S. Labor Relations Bd. 1966).

Saga Food Service of California, Inc., 212 NLRB 786 (1974).

State of New York (State University of New York), 2 NYPERB 4010 aff'd 2 NYPERB 9 3070, (N.Y. Pub. Emp. Relations Bd. 1969), conf'd., Wakshull v. Helsby, 315

N.Y.S.2d 371 (N.Y. App. Div. 1970).

State of New York (State University of New York), 4 PERB II 3000.5 (N.Y. Pub. Emp. Relations Bd. 1971).

State of New York (State University of New York), 24 NYPERB 3035 (N.Y. Pub. Emp. Relations Bd. 1991), conf'd, State of New York (State University of New York) v. New York State Public Employment Relations Board, 586 N.Y.S.2d 662 (N.Y. App. Div. 1992).

St. Clare's Hospital and Health Center, 229 NLRB 1000 (1977).

Sure-Tan, Inc. v. National Labor Relations Board, 467 U.S. 883 (1984).

SuperShuttle DFW, Inc., 367 NLRB 75 (2019).

Trustees of the California State University, 29 PERC 156, (Cal. Pub. Emp. Relations Bd. 2004). 
Trustees of Columbia University in the City of New York, 364 NLRB 9 (2016).

United Faculty of Florida v. Board of Regents, State University System, 417 So.2d 1055

(Fla. Dist. Ct. App. 1982).

United Faculty of Florida, Local 1847 v. Board of Regents, State University System, 423

So.2d 429 (Fla. Dist. Ct. App. 1982).

United Parcel Service, Inc., 369 NLRB 1 (2019).

University of California, 7 PERC 14066 (Cal. Pub. Emp. Relations Bd. 1983), aff'd Regents of the University of California v. Public Emp Relations Bd., 715 P.2d 590 (1986).

University of Chicago, 367 NLRB 41 (2018).

University of Chicago v. National Labor Relations Board, 944 F.3d 694, 698 ( $7^{\text {th }}$ Cir. 2019).

University of Iowa/State Board of Regents, PERB Case Nos. 4959 and 5463 (Iowa Pub. Emp't Relations Bd. 1994) Retrieved from https://iowaperb.iowa.gov/sites/ default/files/certifications/state-ue_896-cogs-grad_students.pdf

University Hospital, University of Cincinnati College of Medicine v. State Employment Relations Board, 587 N.E.2d 835 (1992).

University of Massachusetts, Amherst, CERB Case Nos. SCR-2241, CAS-01-3481 (Mass. Labor Relations Comm'n. 2001).

University of Massachusetts, CERB Case No. SCR-01-2246 (Mass. Labor Relations Comm'n. 2002).

University of Massachusetts, Amherst, CERB Case No. SCR-14-3687 (Mass. Labor Relations Comm'n. 2015).

University of Michigan, 1981 MERC. Lab Op 777 (Mich. Emp’t Relations Comm'n. 1981).

University of Minnesota, BMS Case No. 05-PCE-785 (Minn. Bureau of Mediation Servs. 2005) Retrieved from http://mn.gov/bms-stat/documents/repdecisions/ U\%20of\%20M\%20Unit\%20Determination\%20Order.pdf

University of Pittsburgh, 50 PPER 60 (Pa. Labor Relations Bd. 2019).

University of Western Ontario, OLRB Rep. Nov./Dec. 1151 (Ont. Labour Relations Bd. 2007).

University of Washington, WA.PERC Case No. 16288-E-02-2699 (Wash. Pub. Emp't Relations Comm'n. 2003), Retrieved from https://decisions.perc.wa.gov/ waperc/decisions/en/item/171874/index.do

UPMC, 368 NLRB 2 (2019).

Wal-Mart Stores, Inc., 368 NLRB 146 (2019).

Yale University, 330 NLRB 246 (1999).

York University, OLRB Rep. Sept. 683 (Ont. Labour Relations Bd.1975).

York University, OLRB Rep. May 601 (Ont. Labour Relations Bd.1981). 